Klinichna khirurhiia. 2019 January;86(1):61-64.

DOI: $10.26779 / 2522-1396.2019 .01 .61$

\title{
Модель минно-взрывной травмы
}

\author{
Н. А. Чиж, Г. А. Ковалев, И. В. Белочкина, И. П. Михайлова \\ Институт проблем криобиологии и криомедицины НАН Украины, г. Харьков
}

\section{A minefield trauma pattern}

\author{
N. A. Chizh, G. A. Kovalov, I. V. Belochkina, I. P. Mikhailova
}

Institute of Problems in Cryobiology and Cryomedicine, Kharkiv

\begin{abstract}
Реферат
Цель. Создание доступной модели минно-взрывной травмы различной степени тяжести у крыс.

Материалы и методы. Взрывное повреждение мягких тканей бедра крыс моделировали с помощью строительномонтажного пистолета (СМП) и специально разработанной стойки, которая обеспечивала фиксацию СмП во время выстрела. Для имитации повреждения от поражающих элементов в стволе СМП размещали стальные осколки.

Результаты. Макроскопическая оценка повреждений показала, что они имеют признаки, характерные для поражения мягких тканей ударной волной, струей пламени, поражающими элементами. Показана возможность варьировать степень поражения тканей за счет мощности порохового заряда, отсутствия или наличия поражающих элементов. Выводы. Предложенная модель воспроизводит минно-взрывную травму и может быть использована в любой научно-исследовательской лаборатории, занимающейся вопросами экспериментальной медицины.

ключевые слова: минно-взрывная травма; моделирование; мягкие ткани; крысы.

Abstract

Objective. Creation of pattern of a minefield trauma of different severity in the rats.

Materials and methods. A minefield damage of soft tissues of the hip was simulated in rats, using a construction gun (CG) and a specially designed rack, which provided the CG fixation while shooting. The steel shrapnel were put into the CG stem to imitate the damages from the affecting elements.

Results. Macroscopic estimation of the damages have shown, that they have the signs, characteristic for affection of the soft tissues by a shock wave, the flame jet and affecting elements. Possibility to vary the tissues affection degree at the expense of the powder charge size, absence or presence of affecting elements was shown.

Conclusion. The pattern proposed simulates a minefield trauma and may be applied in any scientific-research laboratory, dealing with experimental medicine.

Keywords: a minefield trauma; simulation; soft tissues; rats.
\end{abstract}

В современных вооруженных конфликтах минновзрывные ранения составляют до 70\% всех травматических поражений [1]. Такие ранения сопровождаются тяжелыми повреждениями мягких тканей взрывной волной, обломками, термическим воздействием. Моделирование на экспериментальных животных патологических состояний, имитирующих минно-взрывную травму (МВТ), является необходимым условием для разработки новых и усовершенствования существующих способов лечения МВТ.

Наиболее существенным недостатком имеющихся моделей МВТ in vivo является их труднодоступность. Это обусловлено тем, что для их воспроизведения необходимы использование специальных средств в условиях военного полигона (противопехотных мин [2], электродетонаторов [3], гранат или самодельных взрывных устройств на основе пластида [4]) и специальные разрешения. Кроме того, существующие модели, как правило, предполагают использование крупных экспериментальных животных (свиньи, собаки). Все указанное значительно суживает область их применения в экспериментальной медицине. Цель исследования: создание доступной модели МВТ различной степени тяжести у крыс.

\section{Материалы и методы исследования}

Эксперименты проведены на 20 беспородных белых крысах-самцах массой тела 250-300 г в соответствии с «Общими принципами экспериментов на животных», одобренными I Национальным конгрессом по биоэтике (Киев, 2001) и согласованными с положениями «Европейской конвенции о защите позвоночных животных, используемых для экспериментальных и других научных целей» (Страсбург, 1986). Методики проведения исследований утверждены комиссией по биоэтике Института проблем криобиологии и криомедицины НАН Украины (Харьков).

МВТ моделировали с помощью строительно-монтажных пистолетов (СМП) СМП-3М калибром 12 мм и ПЦ84 калибром 6,8 мм (Россия, ОАО «Тульский оружейный завод») без поршня. Использовали монтажные патроны 
Д-4 (масса заряда 0,43 г, энергоотдача 1173 Дж) и В-6 (масса заряда 0,55 г, энергоотдача 1450 Дж). Использование СМП без поршня позволяет получить ударную волну, которая является в данном случае основным травмирующим агентом. Для имитации повреждения от осколков боеприпаса и вторичных ранящих агентов в стволе СМП на расстоянии 10 см от дульного среза размещали пыж в виде бумажной салфетки, в которую были завернуты стальные осколки размерами $3-5 \times 1,5$ мм и общей массой 0,2 г.

Поскольку для производства выстрела из СМП необходимо плотно прижать его прижимную часть к твердой неподвижной поверхности, для выполнения экспериментов была разработана специальная стойка, которая крепится шпильками к столешнице. Стойка состоит из металлической пластины и закрепленного на ней диска с углублением под прижимную часть СМП. В центре диска имеется сквозное отверстие диаметром 10 мм. Таким образом обеспечивается жесткая фиксация СМП, предотвращается смещение пистолета относительно отверстия и создаются условия для направленного воздействия ударной волны и осколков. На данный способ моделирования МВТ подана заявка на патент Украины (№ a2018 03683 от 05.04.2018 г.).

Для наркотизации животных использовали препарат телазол («Zoetis Inc.», США) в дозе 50 мг/кг внутримышечно. На наружной поверхности бедра крысы выстригали шерсть. Животное фиксировали под металлической пластиной таким образом, чтобы участок бедра, подлежащий травматизации, находился под отверстием. Прижимную часть СМП устанавливали в углубление диска на пластине и осуществляли выстрел.

Было проведено 4 серии экспериментов (по 5 животных в каждой серии): 1 серия (группа Д-4) - использовали патрон Д-4 без пыжа; 2 серия (группа В-6) - использовали патрон В-6 без пыжа; 3 серия (группа Д-4П) - использовали патрон Д-4 с пыжом; 4 серия (группа В-6П) - использовали патрон В-6 с пыжом.

МВТ оценивали макроскопически после выстрела. Проводили осмотр наружной (со стороны выстрела) и внутренней поверхностей бедра. Затем рассекали мягкие ткани до кости таким образом, чтобы плоскость сечения была перпендикулярна поверхности кожи и проходила через центр области травмы, что соответствовало средней трети бедра. После чего выполняли послойную препаровку тканей.

\section{Результаты}

Макроскопическая картина травмы сразу же после выстрела у животных всех серий была практически идентичной. Отмечен ряд общих для всех экспериментов характерных признаков травмы. На наружной поверхности в средней трети бедра визуализировались раны с центральным дефектом тканей: кожи, подкожной жировой клетчатки, мышечно-фасциального слоя. По периметру ран определялось кольцо воздушного осаднения, которое имело вид черной закопченности. Вокруг ран обнаруживались сопутствующие компоненты выстрела в виде отложения копоти и частиц пороха. Шерстный покров был опален потоком огня, возникшего в результате сгорания порохового заряда. Со стороны подкожной клетчатки на коже в области раны были хорошо заметны полнокровие и извитость сосудов, кровоизлияния различной степени выраженности, большей частью в виде петехий. После удаления кожи четко визуализировался дефект мышечно-фасциального слоя овальной формы с неровным, волнообразным краем, размерами несколько меньше дефекта кожи, что, по-видимому, связано с рефлекторным сокращением мышц в ответ на травму. Вокруг дефекта имелась сплошная муфтообразная зона кровоизлияний в виде геморрагического пропитывания (ближе к краю дефекта) и петехий (по периферии зоны дефекта). Входное отверстие продолжалось раневым каналом, который имел изломанное направление и различную ширину. В просвете канала отмечали наличие большого количества частиц пороха, сгустки крови, обрывки поврежденных тканей, шерсть.

У животных группы Д-4 отмечали раны овальной формы без кровотечения. Края ран были относительно ровными с мелкими надрывами. Сопоставить края раны не представлялось возможным («минус-ткань»). Входное отверстие продолжалось слепым раневым каналом глубиной около 2/3 толщи мышечного массива (рис. 1).

У животных группы В-6 определялись раны с неровными краями, по форме близкие к овальной. По форме дефект мышечно-фасциального слоя примерно соответ-

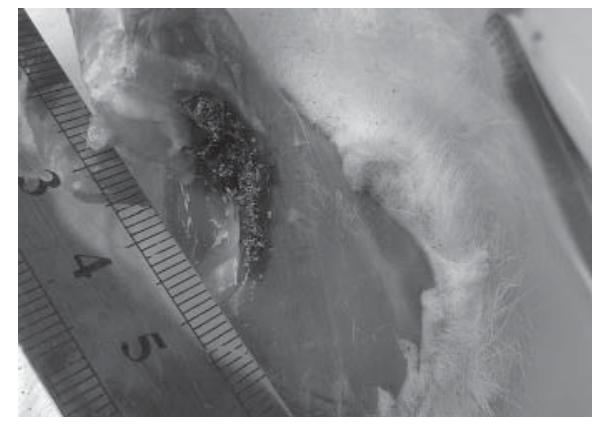

Puc. 1 .

Группад-4. Слепой раневой канал.

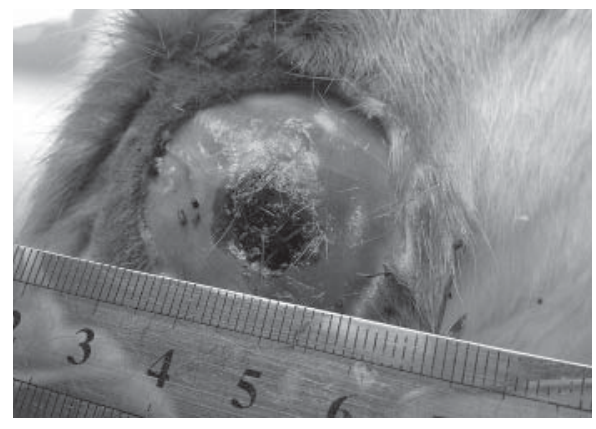

Puc. 2.

Групnа B-6.

Дефектмымечно-фасциального слоя овальной формъ

(после иссечения кожи).

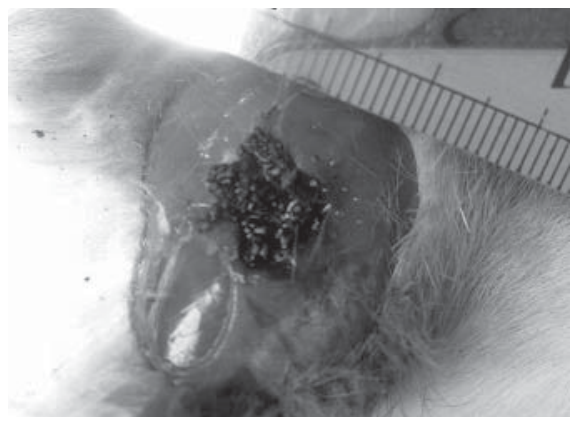

Puc.3.

Группа В-6П.

Дефект мымечно-фасциального слоя звездчатой формы ( после иссечения кожи). 
ствовал дефекту кожи, имел неровные, фестончатые края (puc. 2). Как и у животных предыдущей группы, вокруг дефекта имелась зона кровоизлияний в виде геморрагического пропитывания (ближе к краю дефекта) и петехий (по периферии зоны дефекта), однако степень выраженности кровоизлияний была большей. Входное отверстие продолжалось сквозным раневым каналом, который имел изломанное направление и различную ширину. С внутренней поверхности бедра в проекции входного отверстия определяли выходное отверстие раневого канала. В области выходного отверстия в канале находилось большое количество частиц пороха. Дефект кожи по размеру и форме был близок к кожному дефекту на наружной поверхности бедра. Изменения со стороны подкожной клетчатки были аналогичны изменениям, описанным в области входного отверстия. Размер дефекта мышечнофасциального слоя был примерно в 2 раза больше, чем размер дефекта на наружной поверхности бедра, имел неровные края и форму, близкую к округлой. У всех животных возникало умеренно выраженное кровотечение, которое купировали тампонадой раны.

При осмотре ран крыс группы Д-4П отмечали наличие кожного дефекта неправильной, звездчатой формы. Часть поражающих элементов не проникала глубже кожного покрова. Со стороны подкожной клетчатки были зафиксированы выраженные признаки сосудистых нарушений. В мышечно-фасциальном слое имелись дефекты различной формы и размеров, появившиеся в результате прохождения поражающих элементов заряда. Раневой канал был сквозным, имел изломанное направление и различную ширину на разных участках.

В целом характеристики ран у животных группы В-6П были близки к характеристикам ран у животных группы В-6. Внешний вид бедра в области ранения отличался звездчатой формой кожного дефекта, а также наличием поражающих элементов. Так же, как и в группе B-6, у всех животных возникало кровотечение, которое останавливали тампонадой раны. Дефект мышечно-фасциального слоя отличался звездчатой формой и примерно соответствовал размеру кожного дефекта (рис. 3). Характер кровоизлияний в мышечно-фасциальном слое был таким же, как и в группе В-6, однако они имели большую выраженность. В раневом канале на разной глубине были обнаружены поражающие элементы.

\section{Обсуждение}

В наших экспериментах использование СМП с соответствующими патронами позволяло создать ударную волну, достаточную для получения травмы целевого участка тела крысы - кожи и группы мышц бедра. Входное отверстие продолжалось раневым каналом, который имел изломанное направление и различную ширину, что, по-видимому, можно объяснить особенностями повреждающего действия на ткани взрывной ударной волны. Образовавшиеся при детонации порохового заряда газы вытесняют окружающий воздух, сжимая его и образуя воздушноударную волну, параметры распространения которой в мышечно-фасциальном слое зависят от плотности биологических тканей. Мышцы бедра крысы имеют различ- ную толщину и направленность, между ними находятся фасциальные ложа и клетчаточные пространства. Таким образом, фронт ударной волны на своем пути встречал ткани с очень разной плотностью. Кроме того, сокращение мышц (имеющих различную длину и направление) после травмы также может быть причиной возникновения изломанности раневого канала.

В серии экспериментов, где использовали только заряд с меньшей мощностью (группа Д-4), были получены и меньшие повреждения. Формировался слепой раневой канал без кровотечения. Отсутствие кровотечения, на наш взгляд, можно объяснить гемостатическим эффектом термического воздействия выстрела.

Увеличение мощности заряда и(или) внесение осколочного компонента (использование пыжа) позволяло повысить степень тяжести травмы. Так, в группах В-6, Д-4П и В-6П наблюдали формирование сквозного раневого канала. В отличие от групп Д-4 и Д-4П, использование более мощного заряда (группы В-6 и В-6П) вызывало у всех животных умеренно выраженное кровотечение. Возникновение кровотечения объясняется более выраженным по сравнению с зарядом низкой мощности разрушением тканей с нарушением целостности болышего количества сосудов. При этом влияние пламени и высокой температуры пороховых газов уменьшалось пропорционально глубине раневого канала, соответственно клинически значимый гемостатический эффект этих факторов сохранялся только на небольшой глубине дефекта.

Отличительной особенностью ран в сериях, где использовали пыж (группы Д-4П и В-6П), было наличие кожного дефекта неправильной, звездчатой формы. В группе В-6П дефект мышечно-фасциального слоя также отличался звездчатой формой. Такая форма дефекта обусловлена дополнительным травмирующим действием поражающих элементов заряда, которые, двигаясь с высокой скоростью по хаотической траектории, разрывают биологические ткани в различных направлениях.

\section{Выводы}

1. Предложенная экспериментальная модель характеризуется всеми макроскопическими признаками, характерными для поражения, возникающего вследствие воздействия на животное ударной волны, струи пламени, пороховых газов, поражающих элементов, то есть воспроизводит МВТ. В зависимости от мощности порохового заряда возникает либо слепое, либо сквозное ранение с развитием умеренно выраженного кровотечения. Наличие поражающих элементов мало влияет на площадь кожного дефекта, однако значительно увеличивает тяжесть поражения подлежащих тканей - мышц, сосудов и, по-видимому, нервов.

2. При осуществлении данного способа моделирования МВТ имеется возможность фиксировать шпильками пластину на различном расстоянии от рабочей поверхности и таким образом варьировать степень поражения тканей не только за счет мощности порохового заряда, отсутствия или наличия поражающих элементов, но и путем изменения расстояния от дульного среза до объекта. Исходя из этого, способ также может быть применим и для более крупных лабораторных животных. 
3. Предложенная модель МВТ у лабораторных животных является доступной в любой научно-исследовательской лаборатории, занимающейся вопросами экспериментальной медицины. Перспективой дальнейших исследований может быть микроскопическое изучение тканей в зоне МBТ.

4. При выполнении работы соблюдались все применяемые международные, национальные и институциональные руководящие принципы по уходу и использованию животных.

\section{Підтвердження}

\section{Інформація про фінансування.}

Робота виконана в рамках відомчої НДР Інституту проблем кріобіології і кріомедицини НАН України «Деструктивні та відновні процеси в тканинах in vivo після дії низьких температур та біологічно активних речовин» (шифр 2.2.6.113 № держреєстрації 0117U000849)

Розкриття потенційного конфлікту інтересів.

Автори заявляють, що у них немає конфлікту інтересів. Інформація про внесок кожного учасника.

Н. А. Чиж - концепція і дизайн дослідження, збирання та опрацювання матеріалів, аналіз отриманих даних; Г. А. Ковалев - збирання та опрацювання матеріалів, аналіз отриманих даних, написання тексту; И. В. Белочкина аналіз отриманих даних, написання тексту;

И. П. Михайлова - збирання та опрацювання матеріалів.

Всі автори прочитали та схвалили остаточний варіант рукопису.

Згода на публікацію

Всі автори дали згоду на публікацію цього рукопису.

\section{References}

1. Guriev S, Kukurus J, Jalovenko V, Volna I. Analysis of experience treating gunshot wounds of the extremities. Ekstrena medytsyna vid nauky do praktyky. 2014;2(5):25-32. [In Ukrainian].

2. Soloviyev IA, Titov RV, Shperling IA, Galaka AA, Ambartsumyan SV, Milyaev AV, et al. Features of mine-blast trauma with using of certain types of personal body armor. Vestnik rossiiskoi voenno-meditcinskoi akademii. 2015;(3):128-32. [In Russian].

3. Vengerovich NG, Shperling IA, Yurkevich YV, Vladimirova OO, Alekseyeva II, Shulepov AV, et al. Morphological characteristics of posttraumatic skeletal muscle regeneration after experimental blast injury. Bulletin of Siberian Medicine. 2015;14(4):17-24. doi: 10.20538/1682-03632015-4-17-24. [In Russian].

4. Mykhaylusov RN, Negoduyko VV, Prikhodko YuV. Abiological layer design of fire wounds of soft tissues. Eksperymentalna i klinichna medytsyna. 2016;4:144-7. [In Russian]. 